\title{
Picogram per Day
}

National Cancer Institute

\section{Source}

National Cancer Institute. Picogram per Day. NCI Thesaurus. Code C85778.

Picograms per day. 